\title{
Variability Studies of POD and Seed Characterstics of Albizia Procera in Chhattisgarh
}

\author{
Sunil Kumar Tiwari ${ }^{1 *}$ and S S Dhuria ${ }^{2}$ \\ ${ }^{1}$ Department of Forestry, Wildlife and Environmental Sciences School of Natural Resources, India \\ ${ }^{2}$ Guru Ghasidas Vishwavidhyalaya, Bilaspur, Chhattisgarh, India \\ *Corresponding Author: sunilt167@gmail.com
}

Available online at: www.isroset.org

Received: 25/May/2018, Revised: 06/Jun/2018, Accepted: 19/Jun/2018, Online: 30/Jun/ 2018

\begin{abstract}
Albizia procera is an important agroforestry tree species widely distributed across different agricultural systems of India.. Therefore to identify the best seed source is a big challenge and to understand about the seed morphology, germination and seedling growth of some provenances/ seedsource is an important step in helping identification of suitable provenance for establishment in Chhattisgarh. The present study was conducted in Departmental Nursery to determine the variation in pod and seed characteristics in five provenances namely Bilaspur, Bastar, Korba, Raigarh and Sarguja of Chhattisgarh,India. The studies conducted through the estimation of range, mean, phenotypic and genotypic coefficient of variability, heritability, genetic advance and genetic gain. The present study revealed that highly significant differences among provenances in all studied parameters except pod thickness. Highest variation among provenances in seed traits were observed in seed weight and seed length while seed thickness has the lowest variation. Significant variations were recorded in all the studied parameter. The extent of variation in pod length and seed width was higher as compared to pod width, seed thickness, seed length and no. of seeds per pod, high heritability is recorded in pod length $(46.01 \%)$, seed width $(67.74 \%)$, seed thickness $(45.00 \%)$ so there is scope for considerable genetic gain.
\end{abstract}

Keywords- Variability, seed characteristics, genetic gain, Albizia procera.

\section{INTRODUCTION}

Albizia procera is a large fast growing species that occurs and found in natural forest and agriculture bunds of Chhattisgarh. It is a valuable species which provide wood for variety of purpose, fodder for livestock it is an important agroforestry species ,Due to its multipurpose use and nitrogen fixing ability it is considered as one of the priority species in plantation programs, it is an important species with lot of variability which can be exploited for its improvement in evolving superior seeds, genetic differences associated with the place of origin have been several times as great as that among individual trees with in the population, so it becomes necessary to conduct seed source testing prior to a more intensive breeding work [1], For successful afforestation of any species there is a need of carefully planned and well directed seed source research, and it provides great opportunity to the tree breeder to screen and capture natural variation because the success of the plantation will depend upon proper seed source.

The success of the tree improvement programmes depends upon the determination of amount, type and cause of genetic variability within a species. Thus the objective of this study was to evaluate the variation existing in different provenances of Albizia procera based on seed/pod and germination characteristics, so as to obtain the most suitable provenances for the production of quality seedlings (planting materials) for mass afforestation and agroforestry systems.

\section{RELATED WORK}

Variability studies are the prerequisites for genetic upliftment of any tree species under various agro climatic conditions, $[2,3]$. The significance of variation studies and provenance testing in forest tree improvement is very well realized $[4,5,6,7,8,9,10]$ have reported seed source variability in seed and seedling traits of Indian provenances of A. nilotica. Provenance tests in native species are desirable to screen the available variation for higher productivity and future breeding work [11].studying genetic variability is very important in improving this species in future selections, the present study reports the findings of morphological variations in pod and seed characteristics of Albizia procera. Variations in seed morphological characteristics, germination and seedling growth among provenances have been reported for many forest trees including Faidherbia albida [12]. Variation among the provenances might be attributed to genetic 
differences caused by the adaptation of different provenances to diverse environmental conditions [13] and soil types [14].

\section{MATERIAL AND METHODS}

The fully mature seeds were collected from the five provenances of Chhattisgarh, India( Geographical Location: Table:1). The air dried seeds with a moisture content of 7.660 $\pm 0.84 \%$

To determine the variability in seed and pod morphological characters, seed length, seed width, seed thickness ,seed weight, pod length, pod width, pod thickness ,pod weight were measured for each provenance. A total of 150 seeds per provenance were randomly selected ( 3 replicates of 50 seeds) and organized in a completely randomized design (CRD) for measuring each morphological character (that is, $50 \times 3 \times 5=$ 750 experimental units). Measurement was made on individual seed using a vernier caliper for seed \& pod length, seed $\&$ pod width and seed $\&$ pod thickness and an electronic weighing balance for seed and pod weight.

Data collected on seed morphology were subjected to Analysis of Variance (ANOVA). The coefficient of variation and heritability were calculated using the method Burton and Devane (1953) [15]

Table 1: Geographic Location of pod /seed collection of Albizzia procera in Chhattisgarh[28]

Table 2. Seed characteristics in different provenances of Albizia procera from Chhattisgarh.

\begin{tabular}{|l|l|l|l|l|l|}
\hline Provenances & $\begin{array}{l}\text { Seeds weight } \\
(\mathbf{g m})\end{array}$ & $\begin{array}{l}\text { Seed Length } \\
(\mathbf{c m})\end{array}$ & Seed Width $(\mathbf{c m})$ & $\begin{array}{l}\text { Seed Thickness } \\
(\mathbf{c m})\end{array}$ & $\begin{array}{l}\text { Viability } \\
\text { test }\end{array}$ \\
\hline Bilaspur & $0.086 \pm 0.003^{\mathrm{a}}$ & $0.802 \pm 0.017^{\mathrm{a}}$ & $0.525 \pm 0.022^{\mathrm{a}}$ & $0.218 \pm 0.011^{\mathrm{a}}$ & $100.0^{\mathrm{a}}$ \\
Bastar & $0.032 \pm 0.001^{\mathrm{e}}$ & $0.744 \pm 0.024^{\mathrm{b}}$ & $0.472 \pm 0.018^{\mathrm{a}}$ & $0.194 \pm 0.017^{\mathrm{b}}$ & $100.0^{\mathrm{a}}$ \\
Korba & $0.069 \pm 0.002^{\mathrm{c}}$ & $0.502 \pm 0.019^{\mathrm{d}}$ & $0.302 \pm 0.021^{\mathrm{c}}$ & $0.112 \pm 0.012^{\mathrm{e}}$ & $087.7^{\mathrm{b}}$ \\
Raigarh & $0.073 \pm 0.002^{\mathrm{b}}$ & $0.664 \pm 0.070^{\mathrm{c}}$ & $0.400 \pm 0.012^{\mathrm{b}}$ & $0.171 \pm 0.017^{\mathrm{c}}$ & $097.0^{\mathrm{a}}$ \\
Sarguja & $0.048 \pm 0.002^{\mathrm{d}}$ & $0.636 \pm 0.032^{\mathrm{e}}$ & $0.410 \pm 0.017^{\mathrm{b}}$ & $0.169 \pm 0.020^{\mathrm{d}}$ & $098.5^{\mathrm{a}}$ \\
\hline $\begin{array}{l}\text { ANOVA (One } \\
\text { way) }\end{array}$ & $*$ & $*$ & $*$ & $*$ & $*$ \\
\hline
\end{tabular}

Means within a column followed by same letter are not significantly different $(\mathrm{P} \leq 0.05)$. The data shown are mean $\pm \mathrm{SE}$ of four replicates. Different letters a, b, c and d denote significant difference $(\mathrm{P} \leq 0.05)$ between the treatments.

*Statistically significant difference at $\mathrm{P} \leq 0.0$

\begin{tabular}{|l|l|l|l|}
\hline Provenance & $\begin{array}{l}\text { Latitude } \\
(\mathbf{N})\end{array}$ & $\begin{array}{l}\text { Longitude } \\
(\mathbf{E})\end{array}$ & $\begin{array}{l}\text { Altitude } \\
(\mathbf{m})\end{array}$ \\
\hline Bilaspur & $21^{0} 47^{\prime}$ & $81^{0} 14^{\prime}$ & 265 \\
\hline Bastar & $19^{\circ} .10$ & $81^{\circ} .95^{\prime}$ & 552 \\
\hline Korba & $22^{0} .35^{\prime}$ & $82^{\circ} .68$ & 252 \\
\hline Raigarh & $21^{\circ} .9^{\prime}$ & $83^{\circ} .4^{\prime}$ & 219 \\
\hline sarguja & $22^{\circ} .5^{\prime}$ & $82^{\circ} .5^{\prime}$ & 611 \\
\hline
\end{tabular}

\section{RESULTS AND DISCUSSION}

A significant variation in the seed characteristics of Albizia procera were recorded for different provenances of Chhattisgarh (Table2). The seeds of Bilaspur provenance showed a maximum seed weigh, in contrast the seeds from Bastar recorded the minimum value for seed weight. Highest values for seed length and seed width were obtained for Bilaspur provenance and it was followed by Bastar, Raigarh, Sarguja and Korba respectively. The seed thickness does not show any significant difference across all the provenances.

A significant variation in different pod characteristics was also recorded among the different provenances. A maximum pod length, width and weight were recorded for Bilaspur provenance and it was followed by Bastar, Sarguja, Raigarh and Korba respectively. Average number of seeds per pod was highest in Bastar (12 seeds) provenance and however no significant variation in the number of seeds per pod exist between the other provenances. 
Table 3. Pod characteristics in different provenances of Albizia procera from Chhattisgarh.

\begin{tabular}{|l|l|l|l|l|l|}
\hline Provenances & $\begin{array}{l}\text { Pod weight } \\
(\mathbf{g m})\end{array}$ & $\begin{array}{l}\text { Pod Length } \\
(\mathbf{c m})\end{array}$ & $\begin{array}{l}\text { Pod Width } \\
(\mathbf{c m})\end{array}$ & $\begin{array}{l}\text { Pod Thickness } \\
(\mathbf{c m})\end{array}$ & $\begin{array}{l}\text { Avg. Seeds } \\
\text { per Pod }\end{array}$ \\
\hline Bilaspur & $1.07 \pm 0.14^{\mathrm{a}}$ & $15.6 \pm 1.26^{\mathrm{a}}$ & $2.12 \pm 0.21^{\mathrm{b}}$ & $0.209 \pm 0.16^{\mathrm{a}}$ & $12 \pm 1.01^{\mathrm{a}}$ \\
Bastar & $1.36 \pm 0.22^{\mathrm{a}}$ & $14.1 \pm 2.24^{\mathrm{b}}$ & $2.87 \pm 0.32^{\mathrm{a}}$ & $0.172 \pm 0.07^{\mathrm{b}}$ & $11 \pm 1.07^{\mathrm{b}}$ \\
Korba & $0.89 \pm 0.09^{\mathrm{b}}$ & $11.2 \pm 1.90^{\mathrm{d}}$ & $1.52 \pm 0.17^{\mathrm{c}}$ & $0.124 \pm 0.04^{\mathrm{d}}$ & $08 \pm 1.07^{\mathrm{d}}$ \\
Raigarh & $1.21 \pm 0.11^{\mathrm{a}}$ & $12.2 \pm 1.87^{\mathrm{c}}$ & $1.66 \pm 0.11^{\mathrm{c}}$ & $0.157 \pm 0.04^{\mathrm{c}}$ & $09 \pm 1.11^{\mathrm{c}}$ \\
Sarguja & $1.17 \pm 0.07^{\mathrm{a}}$ & $12.9 \pm 1.08^{\mathrm{c}}$ & $1.65 \pm 0.19^{\mathrm{c}}$ & $0.160 \pm 0.02^{\mathrm{b}}$ & $09 \pm 1.09^{\mathrm{c}}$ \\
\hline $\begin{array}{l}\text { ANOVA (One } \\
\text { way) }\end{array}$ & $*$ & $*$ & $*$ & $*$ & $*$ \\
\hline
\end{tabular}

Means within a column followed by same letter are not significantly different $(\mathrm{P} \leq 0.05)$. The data shown are mean $\pm \mathrm{SE}$ of four replicates. Different letters a, b, c and d denote significant difference $(\mathrm{P} \leq 0.05)$ between the treatments.

*Statistically significant difference at $\mathrm{P} \leq 0.05$

The variation refers to the differences in individuals for a particular parameter, these differences may partly due to the genetic factors and partly due to environmental factors the observed value of trait is the phenotypic value of that individual. Genetic parameters were worked out with regard to estimates of heritability, (broad sense), genetic advance (at 5\% selection intensity), and genetic gain. Pooled data were used to compute total variance of different pod-seed traits which showed that genotypic ,phenotypic, and environmental variance were calculated highest for seed germination $(1.23,20.77$, and 19.54) respectively and lowest corresponding values $(0.009,0.020$ and 0.011 respectively) were recorded for seed thickness. Seed length showed highest $(29.52,85.21$ and $79.94 \%)$ values for genotypic, phenotypic and environmental coefficient of variability, respectively. Whereas, almost all the seed traits exhibited lower genotypic, phenotypic and environmental variance as well as coefficient of variability. The lowest values for genotypic coefficient of variance, phenotypic and environmental coefficient of variance was recorded for seed germination $(1.55,6.37$ and $6.17 \%))$. The computed data indicated genotypic variance and coefficient of variability lower than phenotypic and environmental variance and coefficient of variability for all the pod- seed characters (Table4). As far as broad sense heritability and genetic advance for various pod traits are concerned, pod length exhibited highest (46.01 and $1.3 \%$ ) values, and lowest for pod width.

The values for genetic gain (Table 4)for pod characteristics, highest for pod width rather than pod length. As far as broad sense heritability, genetic advance and genetic gain for various seed traits are concerned, seed width exhibited highest (67.74, 0.245 $\%$ and 51.91), seed length (12.0, 0.14, and 20.93) had lowest values for broad sense heritability, genetic advance, genetic gain respectively. All the other pod-seed traits had less than $50 \%$ broad sense heritability.

For the implementation of the observed provenantial variations it is prerequisite to know the extent of variations and also that whether they are due to genetic or environmental factors. Hence information on variations among the desirable parameters important for an elite forest tree breeding programme[21]. Any forest tree species exhibiting a wide range of variability in terms of parameter values like standard deviation, standard error, variance, co-efficient of variation and genotypic, phenotypic and environmental co-efficient of variations provides wide scope for the manipulation of desired traits in a particular tree improvement programme. In the present work we observed that the above mentioned parameter values showed a wide variation in terms of seed and pod characteristics of Albizia procera across different provenances of Chhattisgarh. High broad sense heritability coupled with high genetic advance and genetic gain was observed for seed width (67.74, 0.245 and 51.91\%) among various pod-seed traits (Table 4).. High genotypic and environmental coefficient of variance for pod and seed characters revealed that these traits are controlled partially by genetic as well as environmental factors. Similar results have been reported by [16] for Prosopis cineraria and [17] for Dalbergia sissoo. These results are important for germplasm collection, and subsequent selection of superior genotypes, [18,19,20,21]. Variation among seed provenances with respect to seed traits (length, width, thickness and weight) have earlier been reported in many species including F. albida, Acacia karroo [22], Pinus roxbrughii [23],Dalbergia melanoxylon [24], and Celtis australis [25]. Pongammia pinnata [26], Jatropha curcas [27]. 
Table 4.Estimates of genotypic .phenotypic and environmental variance and their coefficients for various pod and seed characteristics of Albizia procera

\begin{tabular}{|l|l|l|l|l|l|l|l|}
\hline Parameter & $\begin{array}{l}\text { Pod } \\
\text { length }\end{array}$ & $\begin{array}{l}\text { Pod } \\
\text { width }\end{array}$ & $\begin{array}{l}\text { No of } \\
\text { seeds } \\
\text { /pod }\end{array}$ & $\begin{array}{l}\text { seed } \\
\text { length }\end{array}$ & $\begin{array}{l}\text { seed } \\
\text { width }\end{array}$ & $\begin{array}{l}\text { seed } \\
\text { thickness }\end{array}$ & $\begin{array}{l}\text { Ger } \\
(\%)\end{array}$ \\
\hline Genotypic Variance & 0.866 & 0.021 & 0.89 & 0.039 & 0.021 & 0.009 & 1.23 \\
\hline Phenotypic Variance & 1.882 & 0.049 & 2.006 & 0.325 & 0.031 & 0.02 & 20.77 \\
\hline Environmental Variance & 1.116 & 0.028 & 1.116 & 0.286 & 0.01 & 0.011 & 19.54 \\
\hline Genotypic Coefficient Of Variance & 7.04 & 7.39 & 9.63 & 29.52 & 30.70 & 55.16 & 71.6 \\
\hline Phenotypic Coefficient Of Variance & 10.39 & 11.29 & 14.45 & 85.21 & 37.30 & 82.22 & 1.55 \\
\hline Environmental Coefficient Of Variance & 8.00 & 8.54 & 10.78 & 79.94 & 21.19 & 60.98 & 6.37 \\
\hline Heritability & 46.01 & 42.86 & 44.37 & 12.00 & 67.74 & 45.00 & 6.17 \\
\hline Genetic Advance & 1.3 & 0.195 & 1.294 & 0.14 & 0.245 & 0.132 & 5.92 \\
\hline Genetic Gain & 9.84 & 9.95 & 13.20 & 20.93 & 51.91 & 7.74 & 0.132 \\
\hline
\end{tabular}

\section{CONCLUSION AND FUTURE SCOPE}

There is a possibility of genetic improvement in Albizia procera based on studied parameters. The high value of heritability in case of podlength, seedwidth indicates that they are under genetic control however except seed length genetic advance and genetic gain in all studied parameter is quite low. Bilaspur provenance is considered best seed source on the basis of pod and seed morphological characteristics for future genetic improvement programme of Albizia procera.

\section{REFERENCES}

[1] R. A. Sniezko, and H. T. L Stewart. "Range wise provenance variation in growth and nutrition of Acacia albida seedlings propagated in Zimbabwe”. For. Eco. Mgmt., 27: 179-197. 1989

[2] NK Sharma, U Burman, JC Tewari , MD Bhora, L N Harsh. " Variability studies in pod and seed characteristics of Prosopis juliflora” DC. Indian Journal of Forest, 17 (2): 161-165. 1994

[3] R K Vakashasya, O P Rajora and M S Rawat. "Seed and seedling traits of Dalbergia sissoo and variation studies among 10 sources in India." Forest Ecology and Management.48: 265-275. 1992

[4] R. Salazar. " Genetic variation in 16 provenances of Acacia mangium at nursery level in Turrialba", Costa Rica . CATIE, Costa Rica , p. 171989

[5] K Isik. "Altitudinal variation in Pinus brutia Ten: Seed and seedling characteristics". Silvae genetica, 35: 58-67. 1986

[6] M Mehta and D N Sen. "Seed characteristics and growth pattern of seedlings in some trees of Indian Arid Zone". Annals of Arid Zone 34: 65-66. 1995.

[7] P. Shiv Kumar, A.CBanerjee "Provenance trials of Acacia nilotica". Journal of Tree Sciences 5(1): 53-56. (1986).

[8] R. S Mathur,K. K. Sharma, and M. M. S Rawat,. 1984. "Germination behaviour of various provenances u of Acacia nilotica spp".Indian Forester 110: 435-449. 1984.

[9] G.S. Bagchi, and N.D. Dobriyal, "Provenance variation in seed parameters of Acacia nilotica."Indian Forester, 116: 958-961. 1990.

[10] H. S Ginwal, M. Gera and R. L. Srivastava ." Seed source variability in some seed and seedling characteristics of twenty provenances of Acacia nilotica Willd. ex. Del." Range Management \& Agroforestry 17 (1): 49-59. 1996.
[11] J. Burley and P. J. wood, “ A Manual on Species and Provenance Research with Particular Reference to Tropics" Commonwealth Forestry Review, Oxford. 1976.

[12] O G Dangasuk, P Seurei, S Gudu. "Genetic variation in seed and seedling traits in 12 African provenances of Faidherbia albida (Del.) A. Chev. at Lodwar, Kenya" Agrofor. Syst. 37:133-141. 1997.

[13] HS Ginwal, SS Phartyal, PS Rawat, RL Srivastava. "Seed source variation in morphology, germination and seedling growth of Jatropha curcas linn in central India." Silvae Genet. 54(2): 76-79. 2005.

[14] H.Elmagboul, S.Mahgoup, A.Eldoma. "Variation in seed morphometric characteristics and germination of Acacia tortilis subspecies raddiana and subspecies spirocarpa among three provenances in Sudan.” Global J. Bio-Sci. Biotechnol. 3(2): 191196. 2014.

[15] G.W Burton and E.W. Devane, 1953. "Estimating hereditary in fall Festuca arrundinuca. Gomenticatged clonal material." Agriculture Journal, pp.78-81,195

[16] R Bahadur, M S Hooda. "Genetic variability and correlation studies for some pod and seed traits in Khejri (Prosopis cineraria (L.) Druce).” Indian Journal of Forest, 18(2): 161-164. 1995.

[17] AK Uniyal,B.P Bhatt, and NP Todaria. "Provenance variation in seed characteristics of Grewia oppositifolia Roxb. - A promising agroforestry tree crop of Central Himalaya, India." Indian Journal of Forestry 25(2): 209-214. 2002

[18] R S Dhillon, S S Bisla, RPS Tomer. "Variability studies of seed characters in Shisham (Dalbergia sissoo Roxb.)" Indian Journal of Forestry, 18(1): 53-55, 1995

[19] P.W Volker, Dean, W.N. Tibbits, and I.C. Ravenwood. "Genetic parameters and gain expected from selection in Eucalyptus globulas in Termania." Silvae genetica. 39(1): 18-21. 1990.

[20] B Singh, B.P Bhatt, "Provenance variation in pod, seed and seedling traits of Dalbergia sissoo roxb. central Himalaya, India." Tropical Agricultural Research \& Extension”. 2008

[21] HW Johnson, HF Robinson, RF Vomstock.. "Estimates of genetic and environmental variability in soyabean". Agronomy Journal 47:314-318. 1955

[22] R.M. Abdelkheir, AM Ibrahim, AA Khalill. "Provenance variation in seed and germination characteristics of Acacia karroo", Sudan Silva, 9(2), 14-26, 2003.

[23] SK Ghildiyal, CM Sharma, S Gairola "Additive genetic variation in seedling growth and biomass of fourteen Pinus roxburghii provenances from Garhwal Himalaya". Indian J. Sci. Technol. 2(1): 37-45. 2009.

[24] E Amri, HVM Lyaruu, AMS Nyomora, ZL Kanyeka, " Effect of timing of seed collection and provenance on seed viability and germination of Dalbergia melanoxylon" Bot. Res. J,1, 82-88.2008. 
[25] B Singh, BP Bhatt, P Prasad. "Variation in seed and seedling traits of Celtis australis, a multipurpose tree, in Central Himalaya," India. Agrofor. Syst. 67(2):115-122, 2006.

[26] V.M.Police Patil,H Shivanna, P.surendra,G.O. Manjunath,A Krishna and G.V.Dasar. "Variability studies for seed and seedling traits in pongamia pinnata(L.)Pierre”. Karnatka J Agric.Sci .24(2): (201-203) 2011.

[27] Sandeep Sharma and Arun Kumar "Variability studies of fruit and seed characterstics in Jatropha(Jatropha curcas L) in Himachal Pradesh." International journal of Farm sciences 3(1): 70-76,2013.

[28] S.K. Tiwari and SS.Dhuria . "Variation in seed and seedling characters of Albizzia procera with in various provenances of Chhattisgarh, India.” IJSR, vol 6 issue 3, 2017

\section{Authors Profile}

Sunil Kumar Tiwari is working as Asst. professor of Forestry in Kamla Nehru College , Korba (CG). and pursueing Phd from Guru Ghasidas Vishwavidhyalaya, Bilaspur, Chhattisgarh. his research interest focus on tree improvement. 